\title{
The Impact of Marketing Promotion through Social Media on People's Buying Decision of Lenovo in Internet Era: A Survey of Social Media Users in Indonesia
}

\author{
Felix Pratama Chianasta ${ }^{1}$, Sandy Wijaya ${ }^{2}$ \\ * Department of Business Administration, President University, Indonesia \\ ${ }^{* * *}$ Department of Business Administration, President University, Indonesia
}

\begin{abstract}
In today's marketing, promotion has become one of the most important factors in doing business. Hereby, the aim of this research is to identify and find out how is the social media have impact on marketing promotion in Indonesia. This survey has been done with a descriptive analysis, with reliability test, classical analysis which includes normality test, heteroscedasticity test, as well as the multicollinearity test, with the data from 205 samples. With the result of this survey, the impact of marketing promotion through social media is not positive for Lenovo this far. The survey shows that Lenovo has not done an effective marketing promotion through social media in Indonesia, as we compare it to the studies before that shows great influence of social media to people's buying decision from the other brand. Thus, Lenovo's marketers have to do a better job in order to attract Indonesian attention to their brand and products in the social media.
\end{abstract}

Index Terms- Buying Decision, Indonesia, Marketing, Promotion, Social Media

\section{INTRODUCTION}

$\mathrm{M}$ arketing is considered as one of the most important aspects in retail business. Many of companies all over the world are using internet to promote their products and social media is one of their biggest role in internet marketing. Social media are being used to promote or advertise their products. With high number of social media users, it has great advantage for the company as a lot of people will recognize or see what their markets. The previous studies show that social media have really huge impact in human lifestyle (Clarfloaty, 2012)[1], thus marketing in the social media is an easy mass communication for the company's marketing.

By knowing that social media have a big impact in marketing (Brittanyh, 2013)[2], the authors would like to show the power of social media in Indonesia. Internet in Indonesia is spreading very quickly towards most of the part of the country (Pitoyo, 2013)[3]. Even though it has spread at a good pace, the development of the technology itself is not as sophisticated as other countries, even compared to their neighboring countries (DailySocial, 2013)[4]. Even with their lacks of supporting technology, Indonesian has used social media daily. Social media contributed big part of internet usage, as most of Indonesian like to communicate and socializing with each other. With $96 \%$ of Indonesian are social media users (Reed, 2013)[5], Lenovo having a big opportunity in promoting their brand or product through social media. Not only advertising, social media also enable Lenovo to have more personalized relationship with their customers which can increase their brand image as well as brand awareness to Indonesian as they like to have more personal relation (Brittanyh, 2013)[2]. Lenovo are also able to give knowledge about their products to the customers who have less knowledge and wanted to know more.

In this research paper the authors used descriptive research. The authors have spread the questionnaire through several social media such as Facebook, Twitter, and Instagram, so the authors are able to show that social media is a good way for Lenovo to market their products and brand. The questionnaire was made with Google Drive.

There are four parts of this research paper. First part is the abstract and introduction of the impact of social media on marketing in Indonesia. Second part the authors share the literature review of the research. Third part the authors share the descriptive review that the authors get from the questionnaire. Lastly the authors have conclusion from the research and future implementation.

\section{LITERATURE REVIEW}

\subsection{Promotion}

Promotion is the way of communicating between product and customers to influence their buying decision (Kotler \& Armstrong, 2010)[6]. Another definition of promotion is to communicate with customer with the similar caption like advertisement, sales promotion, public relation, exhibitions, and direct mail (Baker, 2003)[7].

Nowadays promotion has really big impact towards people's buying decision. A good promotion can help a company to be success in doing business. A good company will always have a lot of promotion in order to attract their customers so that they are able to recognize the brand awareness of the company as well as their products. In this internet era, social media is one of the best ways that can be used to promote the company's brand awareness as social media is used throughout the world, and Indonesia is one of the biggest social media users in the world with $96 \%$ of social media users in Indonesia (Reed, 2013)[5], so that it will be good opportunity for company to implement social media as their marketing strategy. 
The authors have considered some social media that mostly used in Indonesia and can be used to promote their image or product in each media:

\subsubsection{Promotion through Facebook}

Facebook is one of the most popular social media in the world with around 1.15 billion users worldwide. According to kompas.com (Deliusno, 2013)[8] there are 33 million users logged in to Facebook everyday and 28 million of them access it through their mobile device. People used Facebook to connect and communicate with other users. In Facebook people are able to upload their photos and videos, play games, join groups, chatting, personal message, like (Facebook terms to show your favorite page) a fan page. With the help of Facebook, people are able to reach and stay connected with millions of users and shares information amongst them (Gurnelius, 2011)[9].

There are two advantages of Facebook that really useful for company's marketing promotion. First, through social media such as Facebook, the company is able to promote their products to customers who use Facebook, and it only requires a little amount of expense. Second, it is easier to identify the target market by joining the groups which has similar needs and interests, and there are some features that really helpful for companies which are, status updates, photos and videos upload, wall, and chat (Puntoadi, 2011)[10].

\subsubsection{Promotion through Twitter}

Twitter emerged as a social media that enables its users to send a 140 character text to express their thoughts and share it to their friend, or in twitter they call it 'tweets'. Twitter is the second largest social media in the world with their more than 500 million users tweeting 58 million tweets in a day. Twitter was launched in 2006 by Jack Dorsey and now it is included in the top ten most visited websites in the world (Huffington Post, eMarketer, 2013)[11]. Indonesia is the fourth largest twitter users worldwide, and Jakarta is the number one city in terms of number of tweets per second as $87 \%$ of twitter users in Indonesia are using mobile devices to access their twitter account (Reed, 2013)[5]. There are some features that are provided by twitter, such as following, which enables the users to follow other users, twitting, so that the users can express about what happened. There are others features such as replies, retweets, and trending topics (Brown, 2011)[12]. The benefit that users can have from twitter is that they can share contents and get involved in conversations thus it gives values to the users.

\subsubsection{Promotion through Instagram}

Instagram was founded by Kevin Systrom and Mike Krieger in October 2010. Instagram is social media that specialized in sharing pictures. The purpose of instagram itself is to share moments that happened around the user. Instagram have grown very quick, as they already have around 150 million users to date (TeknoUp, 2013)[13]. They also have a rapid growth as the only had 100 million users in February 2013 (Panji, 2013)[14]. Instagram have some features that attracts the users, one of the feature is to help the users to have better looking photos with their specialized photo filter. Another feature is the ease of sharing photos and fast \& efficient photo upload (Stephanie, 2012)[15].

\subsection{Buying Decision}

Customer buying decision is the important factor for company's revenue and it is important for the marketer to understand about it. To understand the factors that influence buying decision the company should figure out through research. By doing research the company will understand about what the customers will buy, when they buy, where they buy, and why they buy the products (Kotler \& Armstrong, 2010)[6]. There are some elements that affect on customer's buying decision, which are the consumer's consciousness of a product so that they are willing to find more information, the consumer's consideration of many alternative products to choose, and the process from consciousness through consideration until purchasing the product (Dave, 2008)[16].

\section{METHODOLOGY}

\subsection{Sampling}

The population used for this survey is the users of Facebook, Twitter, and Instagram in Indonesia. The unit of analysis is the users of Facebook, Twitter, and Instagram that ever looked at Lenovo's promotion in Facebook, Twitter, and Instagram. The authors spread the questionnaire throughout the internet, through social media such as Facebook, Twitter, and Instagram. There is a problem that faced by the authors which is the difficulty to have valid respondents because the authors do not know each respondents profile before the respondents filled the questionnaire. To know the minimum number of questionnaires, the authors will use the following formula:

$(\mathrm{N}>50+8 \mathrm{~m})$

Explanation:

$$
\mathrm{N}=\text { Sample Size }
$$

$\mathrm{m}=$ number of questions available in the questionnaire

There are 16 questions available in the questionnaire, so $\mathrm{N}>$ $50+8(16)$. The result is $N>178$, it means the authors have to find more than 178 respondents. Therefore, the authors prepare minimum number of 200 questionnaires.

The authors asked about the respondents' name, age, and gender. The authors also asked about the frequency of the respondents visiting each social media and if they had followed or liked Lenovo's official account in Facebook, Twitter, and Instagram. Lastly, the respondents were asked if they owned a Lenovo's smart phone.

\subsection{Data Collection}

To collect the data, the questionnaire was spread through internet with third-party survey, which is Google Drive. The questionnaire shared in social media which are Facebook, Twitter, and Instagram and the qualified potential correspondents are those who use Facebook, Twitter, and Instagram and had seen Lenovo's promotion on each social media.

\section{RESULT}

\subsection{Descriptive Analysis}

This descriptive analysis is to explain the result of the data from the questionnaires that have been fulfilled by survey's respondents. The total sample of this survey is 205 respondents which have seen Lenovo's promotion in Facebook, Twitter, and Instagram. The variables that will be discussed are gender, age, the frequency of visited Facebook, the frequency of visited Twitter, the frequency of visited Instagram, like-ing the Lenovo's 
fan page or not, following the Lenovo's twitter or not, following the Lenovo's Instagram or not, and owning a Levono's smartphone or not.

\subsubsection{Respondents' Description Based on Gender}

The respondents' data from the surveys' questionnaire shows that there are 103 male respondents and 102 female respondents which have seen Lenovo's promotion on Facebook, Twitter and Instagram. This shows that the ratios of male and female respondents are almost equal.

\subsubsection{Respondents' Description Based on Age}

The age is categorized as below 20 years old, 21 to 25 years old, 26 to 30 years old, and above 30 years old. The respondents' data from the survey's questionnaire shows that there are 120 respondents are below 20 years old, 61 respondents are categorized as 21 to 25 years old group, 16 respondents are categorized as 26 to 30 years old group, and lastly there are 8 respondents are above 30 years old. This shows that the majority of the respondents are people who aged below 20 years old.

4.1.3 Respondents' Description Based on the Frequency of Visiting Facebook

The frequencies of visiting Facebook are separated into three options, which are everyday, $2-4$ times in a week, and $1-$ 2 times in a month. The respondents' data from the survey's questionnaire shows that there are 79 respondents are visiting Facebook everyday, 74 respondents are visiting Facebook $2-4$ times in a week and 52 respondents are visiting Facebook $1-2$ times in a month.

4.1.4 Respondents' Description Based on the Frequency of Visiting Twitter

The frequencies of visiting Twitter are separated into three options, which are everyday, $2-4$ times in a week, and $1-2$ times in a month. The respondents' data from the survey's questionnaire shows that there are 159 respondents are visiting Twitter everyday, 30 respondents are visiting Twitter $2-4$ times in a week and 16 respondents are visiting Twitter $1-2$ times in a month. Most of the respondents are visiting twitter daily.

4.1.5 Respondents' Description Based on the Frequency of Visiting Instagram

The frequencies of visiting Instagram are separated into three options, which are everyday, $2-4$ times in a week, and 1 2 times in a month. The respondents' data from the survey's questionnaire shows that there are 77 respondents are visiting Instagram everyday, 44 respondents are visiting Instagram $2-4$ times in a week and 84 respondents are visiting Instagram $1-2$ times in a month.
4.1.6 Respondents' Description based on like-ing Lenovo's Facebook Fan Page

The result of the survey shows that there are 42 out of 205 respondents are like-ing Lenovo's Facebook fan page and the rest, 163 respondents have not like-ing Lenovo's Facebook fan page.

4.1.7 Respondents' Description based on following Lenovo's Twitter

The result of the survey shows that there are 38 respondents are following Lenovo's Twitter and 167 respondents have not following Lenovo's Twitter.

4.1.8 Respondents' Description based on following Lenovo's Instagram

The result of the survey shows that there are 9 respondents are following Lenovo's Instagram and 196 respondents have not following Lenovo's Instagram

4.1.9 Respondents' Description based on Ownership Status

The result of the survey shows that there are 45 respondents own Lenovo's smartphone while the other 160 respondents do not have Lenovo's smartphone. From the data, the majority of the respondents do not own Lenovo's smartphone.

4.2 Variable Descriptive Analysis

The purpose of descriptive analysis is to figure out the reaction of respondents from the answers that respondents have fulfilled from the questions in the questionnaire. The variable of promotion through Facebook $\left(\mathrm{X}_{1}\right)$ consist of 4 questions, variable of promotion through Twitter $\left(\mathrm{X}_{2}\right)$ consist of 3 questions, variable of promotion through Instagram consist of 3 questions, and Buying Decision (Y) consist of 6 questions.

To interpret the average, the interval is made with this following formula:

$$
\text { interval }=\frac{\text { highest acore-lowest acore }}{\text { total class }}=\frac{5-1}{5}=0.8 \text { ) }
$$

With the interval, the range scale can be made to find out how the respondents average grade of every differentiation and variation element. The range scale is as follows:

$1.00-1.80=$ very unsuitable

$1.81-2.60=$ unsuitable

$2.61-3.40=$ adequate

$3.41-4.20=$ suitable

$4.21-5.00=$ very suitable

4.2.1 Promotion Variable through Facebook

The distribution of respondents answer on promotion variable through Facebook can be seen in the table below:

Table 4.1

\begin{tabular}{|l|l|l|l|l|l|l|l|l|l|l|l|}
\hline & 1 & & 2 & & 3 & & 4 & & 5 & \\
\multirow{2}{*}{ Question } & $\mathrm{F}$ & $\%$ & $\mathrm{~F}$ & $\%$ & $\mathrm{~F}$ & $\%$ & $\mathrm{~F}$ & $\%$ & $\mathrm{~F}$ & $\%$ & Score Average \\
\hline 1 & 13 & $7,3 \%$ & 26 & $14,5 \%$ & 76 & $42,5 \%$ & 69 & $38,5 \%$ & 21 & $11,7 \%$ & 3,29 \\
\hline 2 & 11 & $5,7 \%$ & 13 & $6,8 \%$ & 84 & $43,8 \%$ & 62 & $32,3 \%$ & 35 & $18,2 \%$ & 3,47 \\
\hline 3 & 13 & $6,8 \%$ & 15 & $7,9 \%$ & 83 & $43,7 \%$ & 63 & $33,2 \%$ & 31 & $16,3 \%$ & 3,41 \\
\hline 4 & 12 & $6,8 \%$ & 28 & $15,8 \%$ & 78 & $44,1 \%$ & 53 & $29,9 \%$ & 34 & $19,2 \%$ & 3,34 \\
\hline
\end{tabular}


From Table 4.1 there are some statements made, which are:

1. In the first question, the average score is 3.29 which means Lenovo's promotion in Facebook is made consumer and potential consumer connected easier with Lenovo marketing is adequate with respondents' answers

2. The average of the second question is 3.47 which means Lenovo inform their products by posting status and upload photos is suitable with the respondents answers

3. The average of the third question is 3.41 which means illustration/pictures in Lenovo advertisement in Facebook are interesting is suitable with the respondents answers
4. The average of the forth question is 3.34 which means banner is one of the advertisement media in Facebook to show Lenovo's latest product is suitable with the respondents answers

5. Overall, the respondents' response of promotion through Facebook is 3.38 which mean it is adequate with respondents' answers. Thus, Lenovo's promotion through Facebook is not effective enough to grab Facebook's users' attention.

\subsubsection{Promotion Variable through Twitter}

The distribution of respondents answer on promotion variable through Twitter can be seen in the table below:

Table 4.2

\begin{tabular}{|l|l|l|l|l|l|l|l|l|l|l|l|}
\hline & 1 & & 2 & \multicolumn{1}{l}{} & 3 & & 4 & 5 & \\
Question & $\mathrm{F}$ & $\%$ & $\mathrm{~F}$ & $\%$ & $\mathrm{~F}$ & $\%$ & $\mathrm{~F}$ & $\%$ & $\mathrm{~F}$ & $\%$ & Score Average \\
\hline 1 & 12 & $6,7 \%$ & 25 & $13,9 \%$ & 80 & $44,4 \%$ & 54 & $30,0 \%$ & 34 & $18,9 \%$ & 3,36 \\
\hline 2 & 10 & $5,5 \%$ & 23 & $12,6 \%$ & 67 & $36,8 \%$ & 59 & $32,4 \%$ & 46 & $25,3 \%$ & 3,53 \\
\hline 3 & 12 & $6,7 \%$ & 27 & $15,2 \%$ & 69 & $38,8 \%$ & 66 & $37,1 \%$ & 31 & $17,4 \%$ & 3,38 \\
\hline
\end{tabular}

From table 4.2 there are some statements made, which are:

1. In the first question, the average score is 3.36 which means Lenovo promotion in Twitter made consumer and potential consumer connected easier with Lenovo marketing is adequate with respondents' answers

2. The average score of the second question is 3.53 which means Posting tweets, retweet, are used by Lenovo to inform their products is suitable with the respondents' answers

3. The average score of the third question is 3.38 which means Twitter is one of the advertisement media used by
Lenovo to give benefit to their followers is adequate with respondents' answers

4. Overall, the respondents' response of promotion through Twitter is 3.42 which mean it is suitable with respondents' answers. Lenovo's promotion through Twitter have drawn enough attention from Twitter's users, but it could be improve

\subsubsection{Promotion Variable through Instagram}

The distribution of respondents answer on promotion variable through Instagram can be seen in the table below:

Table 4.3

\begin{tabular}{|c|c|c|c|c|c|c|c|c|c|c|c|}
\hline \multirow{3}{*}{$\begin{array}{l}\text { No. } \\
\text { Item }\end{array}$} & & & \multirow{2}{*}{\multicolumn{2}{|c|}{2}} & \multirow{2}{*}{\multicolumn{2}{|c|}{3}} & \multirow{2}{*}{\multicolumn{2}{|c|}{4}} & \multirow{2}{*}{\multicolumn{2}{|c|}{5}} & \multirow[b]{3}{*}{ Score Average } \\
\hline & \multicolumn{2}{|l|}{1} & & & & & & & & & \\
\hline & $\mathrm{F}$ & $\%$ & $\mathrm{~F}$ & $\%$ & $\mathrm{~F}$ & $\%$ & $\mathrm{~F}$ & $\%$ & $\mathrm{~F}$ & $\%$ & \\
\hline 1 & 13 & $7,4 \%$ & 29 & $16,5 \%$ & 92 & $52,3 \%$ & 48 & $27,3 \%$ & 23 & $13,1 \%$ & 3,19 \\
\hline 2 & 12 & $6,5 \%$ & 19 & $10,2 \%$ & 82 & $44,1 \%$ & 73 & $39,2 \%$ & 19 & $10,2 \%$ & 3,33 \\
\hline 3 & 14 & $7,9 \%$ & 27 & $15,2 \%$ & 88 & $49,4 \%$ & 51 & $28,7 \%$ & 25 & $14,0 \%$ & 3,22 \\
\hline & & & & & & & & & & Total Average & 3,25 \\
\hline
\end{tabular}

From table 4.3 there are some statements made, which are:

1. In the first question, the average score is 3.19 which means Lenovo promotion in Instagram made consumer and potential consumer connected easier with Lenovo marketing is adequate with respondents' answers

2. The average score of the second question is 3.33 which means Posting photos in Instagram are used by Lenovo to inform their products is adequate with respondents' answers

3. The average score of the third question is 3.22 which means Photos shared by Lenovo is interesting is adequate with respondents' answers
4. Overall, the respondents' response of promotion through Instagram is 3.25 which mean it is adequate with respondents' answers. Lenovo's promotion through Instagram has drawn the least attention compared with Facebook and Twitter. Lenovo need to readjust their promotion strategy through Instagram to gain more attention from Instagram users.

\subsubsection{Buying Decision Variable}

The distribution of respondents answer on buying decision variable can be seen in the table below: 
Table 4.4

\begin{tabular}{|c|c|c|c|c|c|c|c|c|c|c|c|}
\hline \multirow{2}{*}{$\begin{array}{l}\text { No. } \\
\text { Item }\end{array}$} & \multicolumn{2}{|l|}{1} & \multicolumn{2}{|l|}{2} & \multicolumn{2}{|l|}{3} & \multicolumn{2}{|l|}{4} & \multicolumn{2}{|l|}{5} & \multirow[b]{2}{*}{ Score Average } \\
\hline & $\mathrm{F}$ & $\%$ & $\mathrm{~F}$ & $\%$ & $\mathrm{~F}$ & $\%$ & $\mathrm{~F}$ & $\%$ & $\mathrm{~F}$ & $\%$ & \\
\hline 1 & 26 & $15,9 \%$ & 41 & $25,0 \%$ & 67 & $40,9 \%$ & 38 & $23,2 \%$ & 33 & $20,1 \%$ & 3,05 \\
\hline 2 & 28 & $16,4 \%$ & 34 & $19,9 \%$ & 74 & $43,3 \%$ & 45 & $26,3 \%$ & 24 & $14,0 \%$ & 3,01 \\
\hline 3 & 40 & $24,4 \%$ & 41 & $25,0 \%$ & 71 & $43,3 \%$ & 38 & $23,2 \%$ & 15 & $9,1 \%$ & 2,74 \\
\hline 4 & 18 & $10,8 \%$ & 39 & $23,5 \%$ & 64 & $38,6 \%$ & 51 & $30,7 \%$ & 33 & $19,9 \%$ & 3,20 \\
\hline 5 & 20 & $11,4 \%$ & 29 & $16,5 \%$ & 59 & $33,5 \%$ & 45 & $25,6 \%$ & 52 & $29,5 \%$ & 3,39 \\
\hline 6 & 29 & $16,3 \%$ & 27 & $15,2 \%$ & 61 & $34,3 \%$ & 60 & $33,7 \%$ & 28 & $15,7 \%$ & 3,15 \\
\hline
\end{tabular}

From table 4.4 there are some statements made, which are:

1. In the first question, the average score is 3.05 which means the statement of I observed Lenovo's promotion in Facebook to get updated news of Lenovo is adequate with respondents' answers

2. The average score of the second question is 3.01 which means the statement of I observed Lenovo's promotion in Twitter to get updated news of Lenovo is adequate with respondents' answers

3. The average score of the third question is 2.74 which means the statement of I observed Lenovo's promotion in Instagram to get latest news of Lenovo is adequate with respondents' answers

4. The average score of the forth question is 3.20 which means the statement of I am interested with Lenovo after seeing Lenovo's promotion in the social media is adequate with respondents' answers

5. The average score of the fifth question is 3.39 which means the statement of I have the self cautions to look for further information of Lenovo after seeing Lenovo's promotion in the social media is adequate with respondents' answers

6. The average score of the sixth question is 3.15 which means the statement of I have attracted to buy Lenovo after seeing Lenovo's promotion in the social media is adequate with respondents' answers

7. Overall, the respondents' response of Buying Decision Variable is 3.09 which mean it is adequate with respondents' answers. Thus, Lenovo's promotion through Facebook, Twitter and Instagram did not effective enough to attract and influence people buying decision of Lenovo.

Based on Grace's study on 2013[17] about promotion through social media of Samsung, it shows that Samsung's promotion through social media has good impact on people's buying decision of Samsung. It means that Lenovo has a good opportunity to be successful in promoting their products through social media as well. In order to be successful in promoting through social media, Lenovo has to improve by being more aggressive and giving more promotion through social media just like Samsung or if possible be better than Samsung's promotion.

4.3 Reliability Test

Reliability test is done with SPSS and it is considered as reliable if the Cronbach's Alpha value is more than 0,7

Table 4.6 Reliability Test

\begin{tabular}{|l|l|l|l|l|}
\hline Variable & Cronbach's Alpha & $\mathbf{0 . 7}$ & N of Item & Reliability \\
\hline $\begin{array}{l}\text { Promotion through } \\
\text { Facebook }\end{array}$ & 0,877 & 0,7 & 4 & Reliable \\
\hline $\begin{array}{l}\text { Promotion through } \\
\text { Twitter }\end{array}$ & 0,871 & 0,7 & 3 & Reliable \\
\hline $\begin{array}{l}\text { Promotion through } \\
\text { Instagram }\end{array}$ & 0,823 & 0,7 & 3 & Reliable \\
\hline Buying Decision & 0,886 & 0,7 & 6 & Reliable \\
\hline
\end{tabular}

According to Table 4.6, the reliability test shows that all four variable are reliable since all four variable have Cronbach's Alpha value more than 0,7 which means the questionnaire are reliable.

\section{CONCLUSION AND SUGGESTION}

5.1 Conclusion
Based on the result of the survey there are some conclusion that has been made by the authors. The survey result shows that promotions through social media which are Facebook, Twitter, and Instagram simultaneously have no significant effect for Lenovo's promotion. Many people have not known about Lenovo's activities and have no attraction in social media. From the three social media that the authors used for this research, Twitter have the most impact towards Lenovo's promotion, because Twitter have the most active users amongst other social 
media in Indonesia, whereas, Instagram have the least impact as not many people visit Instagram as much as Facebook and Twitter.

From the survey the authors can conclude that Lenovo's promotion is social media have made some people recognize their brand and influence their buying decision, although some of the people show no interest in buying Lenovo's product even after they have seen Lenovo's promotion in social media.

5.2 Suggestion

The authors have made some suggestions so that Lenovo are able to perform better. First, the authors suggest Lenovo to make more attractive promotion in social media. It is true that Indonesia have a big number of social media users, unfortunately it is not easy to make them get attracted to a specific promotion. However, if Lenovo are able to make some attractive promotion, it will spread very quickly as they tend to promote whatever they like to the social media. Second, there are other promotional tools to help them to increase their brand awareness and it can influence people's buying decision. Other promotional tools such as billboards, TV, Radio, Magazine advertisement are very popular in Indonesia

Lastly the authors would like to recommend for those who want to do research with similar topic, it is best to include other variables that have not been taken in our concern that might affect buying decision, for example promotion through other social media such as, Youtube, Forums, Blogs, and Instant Messenger.

\section{REFERENCES}

[1] Clarfloaty. (2012, November). StudyMode. Retrieved October 10, 2013 , from The Impact of Social Media on Human Resources: http://www.studymode.com/essays/The-Impact-Of-Social-Media-On1229381.html

[2] Brittanyh. (2013, July 31). SocialSpark. Retrieved October 10, 2013, from Social Media Marketing: Benefits and Impact: http://socialspark.com/social-media-marketing-benefits-and-impact/

[3] Pitoyo, A. (2013, September 12). merdeka.com. Retrieved October 10, 2013, from IGF, Indonesia bisa jadi contoh perkembangan internet dunia: http://m.merdeka.com/teknologi/igf-indonesia-bisa-jadi-contohperkembangan-internet-dunia.html

[4] DailySocial. (2013, October 17). TRENOLOGY. Retrieved October 20, 2013, from Kecepatan Internet Indonesia Meningkat Dua Kali Lipat, Masih Tertinggal di ASEAN: http://www.trenologi.com/2013101726052/kecepatan-internet-indonesiameningkat-dua-kali-lipat-masih-tertinggal-di-asean/
[5] Reed, C. (2013, May 9). Indonesia - the world's most social mobile centric country. Retrieved October 10, 2013, from The Wall Blog: http://wallblog.co.uk/2013/05/09/indonesia-the-worlds-most-social-mobilecentric-country/

[6] Kotler, P., \& Armstrong, G. (2010). Priciples of Marketing 13th edition. New Jersey: Pearson Education, Inc.

[7] Baker, M. (2003). The Marketing Book Fifth Edition. London: Butterworth Heinemann

[8] Deliusno. (2013, September 20). Tiap Hari, 33 Juta Orang Indonesia Buka Facebook. Retrieved October 10, 2013, from kompas.com: http://tekno.kompas.com/read/2013/09/20/1629066/Tiap.Hari.33.Juta.Orang .Indonesia.Buka.Facebook

[9] Gurnelius, S. (2011). 30-minute Social Media Marketing. United States: McGraw-Hill Companies.

[10] Puntoadi, D. (2011). Menciptakan Penjualan Melalui Social Media. Jakarta: PT Elex Komputindo.

[11] Huffington Post, eMarketer. (2013, July 13). Twitter statistics. Retrieved October 10, 2013, from Statistic Brain: http://www.statisticbrain.com/twitter-statistics/

[12] Brown, A. (2011). The Tricky Business of Business Tweeting. The Irish Time.

[13] TeknoUp. (2013, September 9). Yahoo News Indonesia. Retrieved october 10, 2013, from Instagram Tembus 150 Juta Pengguna: http://id.berita.yahoo.com/instagram-tembus-150-juta-pengguna043001923.html

[14] Panji, A. (2013, February 28). Kompas.com. Retrieved October 10, 2013, from Pengguna Aktif Instagram Tembus 100 Juta: http://tekno.kompas.com/read/2013/02/28/16120251/pengguna.aktif.instagr am.tembus.100.juta

[15] Stephanie, B. (2012, May 29). Yahoo news. Retrieved October 20, 2013, from The Beginner's Guide to Instagram: http://news.yahoo.com/beginnersguide-instagram-220028085.html

[16] Dave, E. (2008). Social Media Marketing An Hour A Day. Canada: Wiley Publishing.

[17] Grace, A. (2013). PENGARUH PROMOSI MELALUI MEDIA SOSIAL TERHADAP MINAT BELI SAMSUNG BERBASIS ANDROID PADA MAHASISWA UNIVERSITAS SUMATERA UTARA. 51-54

\section{AUTHORS}

First Author - Felix Pratama Chianasta, President University, Email: felixdababycat@gmail.com

Second Author - Sandy Wijaya, President University, Email: sandy.aya93@gmail.com

Correspondence Author - Sandy Wijaya, Email:

sandy.aya93@gmail.com , Contact Number: +6281-281-253-685 